Resumo

\title{
O legado das instalações esportivas dos V Jogos Mundiais Militares: manutenção e emprego
}

Rômulo Barbosa Peruchetti Bsci, Luis Fernando Toledo Leal BSci

Introdução: A realização de um evento esportivo de grande porte como as Olimpíadas e a Copa do Mundo, por exemplo, pode trazer para o país-sede benefícios para toda a sociedade. Além de poder assistir as competições ao vivo, também acontecem melhorias nos transportes públicos (ampliação dos serviços, de infraestrutura, modernização da frota, entre outros); restauração de antigas áreas da cidade, ampliação de serviços coletivos, como aeroportos, rodoviárias, rede hoteleira etc. Além desses aspectos positivos para a sociedade, o esporte como um todo também pode ser beneficiado no presente e no futuro com os legados esportivos deixados após o evento.

Objetivo: Avaliar os legados esportivo após os 5ํ Jogos Mundiais Militares (JMM), ocorridos em 2011, no Rio de Janeiro, conceituado pelo Exército Brasileiro (EB).

Métodos: Para a realização desse estudo foi feita uma pesquisa descritiva, utilizando-se a técnica de estudo de casos, visando obter as informações detalhadas junto às Divisões Administrativas de cada instalação esportiva. A amostra foi composta por quatro instalações desportivas utilizadas como locais de competição durante os V JMM, a citar: campo de futebol, da Escola de Educação Física do Exército; pista de pentatlo militar, do $26^{\circ}$ Batalhão de Infantaria Paraquedista; pista de pentatlo naval, do Centro de Educação Física Almirante Adalberto Nunes e ginásio poliesportivo, da Universidade da Força Aérea.

Resultados: Com base no levantamento dos gastos de cada instalação para sua conservação e os benefícios trazidos para o esporte nas Forças Armadas, buscou-se verificar se as instalações atendiam a definição de legado desportivo para o EB de acordo com a Portaria № 656, de 10 de setembro de 2009, que define a diretriz para os $5^{\circ} \mathrm{JMM}$.

Conclusão: Após análise dos dados coletados, pôde-se concluir que as instalações pós-JMM são um legado para o EB.

Palavras-chave: Conseil International du Sport Militaire - CISM; legado esportivo; exército brasileiro; instalações olímpicas; Rio2011. 